to ensure freedom from noxious fumes, equal and adequate pressure in the tyres, and care in cornering are all factors which may help in preventing car sickness. In older children reading while the car is in motion is sometimes responsible for nausea, which may proceed to emesis. Vomiting is less common when the child is sitting in the front seat. In the case of small children, if the journeys involved are short, the children should be allowed to stand on the seats and look out of the front windows. For long journeys, a good meal taken shortly before starting, together with a dose of antihistaminic appropriate to the child's age, may be sufficient to promote drowsiness, and the journey may be begun with the child lying down comfortably on the back seat and going quietly to sleep.

\section{Lice in Prison}

Q.-As medical officer to a prison I am concerned with the problem of preventing the spread of lice of all varieties. Normally we expect to admit an average of three prisoners with pediculosis pubis daily plus a not always ascertainable number of cases of pediculosis corporis and capitis. We isolate these cases until treatment is complete. The present procedure with regard to prisoners' clothing is that all except blue suits goes through the steam disinfector. The blue suits are sprayed with liquid D.D.T. and kept in a special room which is sprayed with D.D.T. daily. This is because the suits turn brown when treated in the steam disinfector. Are these precautions adequate?

A.-Human body-lice spend nearly all their time on the undergarments, especially those next to the skin. Only in exceptionally heavy infestations is more than an occasional stray louse found on an outer garment such as a serge suit. It is therefore satisfactory to apply a residual insecticide, such as D.D.T., to the undergarments only; sooner or later the lice are bound to be contaminated.

The procedure described in the question appears quite adequate. However, several points call for comment : (1) The temperature required to destroy insect life is much lower than for many bacteria. The eggs of lice are killed by exposure to $54^{\circ} \mathrm{C}$. for five minutes, or $50^{\circ} \mathrm{C}$. for half an hour. Higher temperatures or longer exposures are, of course, necessary in practice, to allow the heat to penetrate the garments. Correct exposure could be determined by experiment and would almost certainly be below the level causing damage to blue suits. (2) "Liquid D.D.T." is presumably D.D.T. dissolved in kerosene. Neither in solution nor as a powder is D.D.T. lethal to nits, though it may persist long enough to kill the young louse on hatching. (3) In other parts of the world, strains of lice immune to D.D.T. have been reported, and it is important to look out for this phenomenon here. These resistant lice may survive an exposure of 24 hours to $10 \%$ D.D.T. powder.

\section{Anaesthesia in E.C.T.}

Q. - Is an anaesthetic really necessary for electro-convulsion therapy?

A.-In electro-convulsion therapy some retrograde amnesia is the rule and patients rarely have any unpleasant memory of the previous treatment. There is therefore little need for an anaesthetic in these circumstances. However, it is now common practice to "soften" the convulsion by the previous administration of a relaxant. In the case of curare and gallamine triethiodide ("flaxedil"), if these drugs are given in a dose just sufficient, say, to make snapping of the finger a little difficult, no anaesthetic is really necessary. When, however, succinylcholine chloride ("scoline") or "brevedil" is used, the fibrillary twitchings which precede the muscular paralysis may be quite unpleasant, and the previous injection of a little thiopentone becomes necessary. An average dose of thiopentone for a healthy male would be $0.2-0.25 \mathrm{~g}$., followed immediately by the succinylcholine, after which the convulsion is induced.

\section{Sweating in Shock}

\section{Q.-Why do shocked patients sweat?}

A.- Sweat glands are innervated, anatomically, by the sympathetic nervous system, although there is doubt as to whether the physiological transmitter at the post-ganglionic nerve ending is acetylcholine or noradrenaline. ${ }^{1}$ Shock is associated with a reduced circulating blood volume, and, as a compensatory measure, vasoconstriction of the cutaneous blood vessels is induced by intense sympathetic overactivity. Although teleologically unfortunate, this efferent sympathetic discharge also involves the fibres supplying the sweat glands and results in the characteristic pale, moist skin of the shocked patient.

REFERENCE

1 Barnet, A. J. (1951). Nature, Lond., 167, 482.

\section{NOTES AND COMMENTS}

Beeswax.-Mr. C. C. Tonsley (Editor, British Bee Journal) writes: My attention has been drawn to the item "Beeswax" ("Any Questions?" August 1, p. 296). While I do not disagree with the answer generally which is supplied to the question, I would like to remedy one error which has been stated. In modern beekeeping paraffin wax combs are not given to the bees. If anything but beeswax were offered to bees they would immediately tear it down and build natural comb in its place. Experiments with which I have been associated, where both plastic and metal combs were given to the bees in an effort to get them to use them, resulted in the bees first coating either the plastic or the metal with a thin layer of beeswax before using them, and unless crowded for space they ignored them. In America there is what is called a three-ply foundation made which is given to the bees to draw out into combs. This, however, consists of two outer sheets of pure beeswax with a thin sheet of carnauba wax sandwiched between. The bees draw this outer beeswax into their comb but they do not reach the midrib of vegetable wax.

Vaccination in Pregnancy.-Dr. Norman TayLor (Geneva) writes: The question recently asked on vaccination in pregnancy (July 25, p. 235) did not include reference to the dangers of yellow fever inoculation during pregnancy, as these two operations are nowadays so often required together and urgently. I presume, on theoretical grounds, since they are both live vaccines, both are equally capable of producing undesirable consequences.

OUR EXPERT writes: Although yellow fever vaccine consists of living virus, there is no evidence of its producing any toxic effects in a pregnant woman, and therefore there is no contraindication to its administration during pregnancy.

Isopropyl Alcohol.-The Isopropyl Alcohol Regulations, 1927 ("Any Questions?" July 11, p. 108), which govern the use of the substance, were suspended in August, 1950. They have not been annulled and therefore, if necessary, could be reimposed.

Corrections.-In the review of Operative Thorakoskopie (Journal, August 1, p. 265) it was stated that Jacobaeus was a Croatian surgeon. He was, in fact, Swedish.

The reference to Dr. E. Parry Jones in Mr. H. Vincent Corbett's letter in the Journal of August 8 (p. 340) was to his book, Kielland's Forceps (1952, Butterworth, London), and not to his letter which appeared in the Journal of June 6 (p. 1278).

All communications with regard to editorial business should be addressed to THE EDITOR, BRITISH Medical Journal, B.M.A. House. TAvistoc SOUARE, LoNDON, W.C.1. TElePHONE: EUSTON 4499 . TELEGRAMS Aitiology, Westcent, London. ORIGINAL ARTICLES AND LETTERS forwarded for publication are understood to be offered to the Britlsh Medical Journal alone unless the contrary be stated.

Authors desiring REPRINTS should communicate with the Publishing Manager, B.M.A. House, Tavistock Square, W.C.1. on receipt of proofs Authors overseas shonld indicate on MSS. if reprints are required, as proofs are not sent abroad.

DVERTISEMENTS should be addressed to the Advertisement Manager. B.M.A. House, Tavistock Square. London, W.C.1 (hours 9 a.m. to 5 p.m.). TelephONE: EUSTON 4499. TelbGrams: Britmedads, Westcent, London.

MEMBERS' SUBSCRIPTIONS should be sent to the SECRETARY of the Association. TElephone: EUSTON 4499. Telegrams: Medisecra.

B.M.A. Scotrish OFFICE: 7, Drumsheugh Gardens, Edinburgh. 